\title{
Growing nanotech trade hit by questions over quality
}

\section{Jim Giles, London}

The surge of interest in nanotechnology has created buyers and sellers of materials who aren't properly equipped to do business, analysts have warned.

A survey of nanotechnology companies has revealed a series of problems with the supply of nanomaterials - tiny tubes, wires and cages with dimensions of just billionths of a metre. Batches may be contaminated or the nanoparticles are improperly shipped and clump together during delivery. "We heard one horror story after another," says Matthew Nordan of Lux Research, the New York-based consulting company that published the survey on 8 December.

One semiconductor company found that almost one-third of a sample of carbon nanotubes it had purchased consisted of iron left over from the production process. "Not only is the iron not what the lab paid for, it's a contaminant that would never be allowed in a semiconductor fabrication facility," notes the report, which drew on interviews with more than 100 managers.

Nordan says that the recent explosion in research funding for nanotechnology is partly to blame. In the United States, government spending in the field has increased sixfold since 1997 and now stands at almost $\$ 1$ billion a year. Nordan and other industry experts suggest that customers and suppliers have rushed into the field, and have yet to develop good systems for working with each other.

Some of the worst complaints concerned university laboratories that sell nanomaterials as a side business. One buyer complained to Nordan that "every professor who wants a beach house, and who works on nanosomething, has started a company".

But customers also come in for criticism. Peter Eklund, a nanotechnology researcher at Pennsylvania State University in University Park, is a founder of CarboLex, a nanomaterials supplier based in Lexington, Kentucky. Eklund says he has received only two or three complaints in seven years of business, and all have related to poor handling by researchers. One customer complained that the tubes were shoddy, for

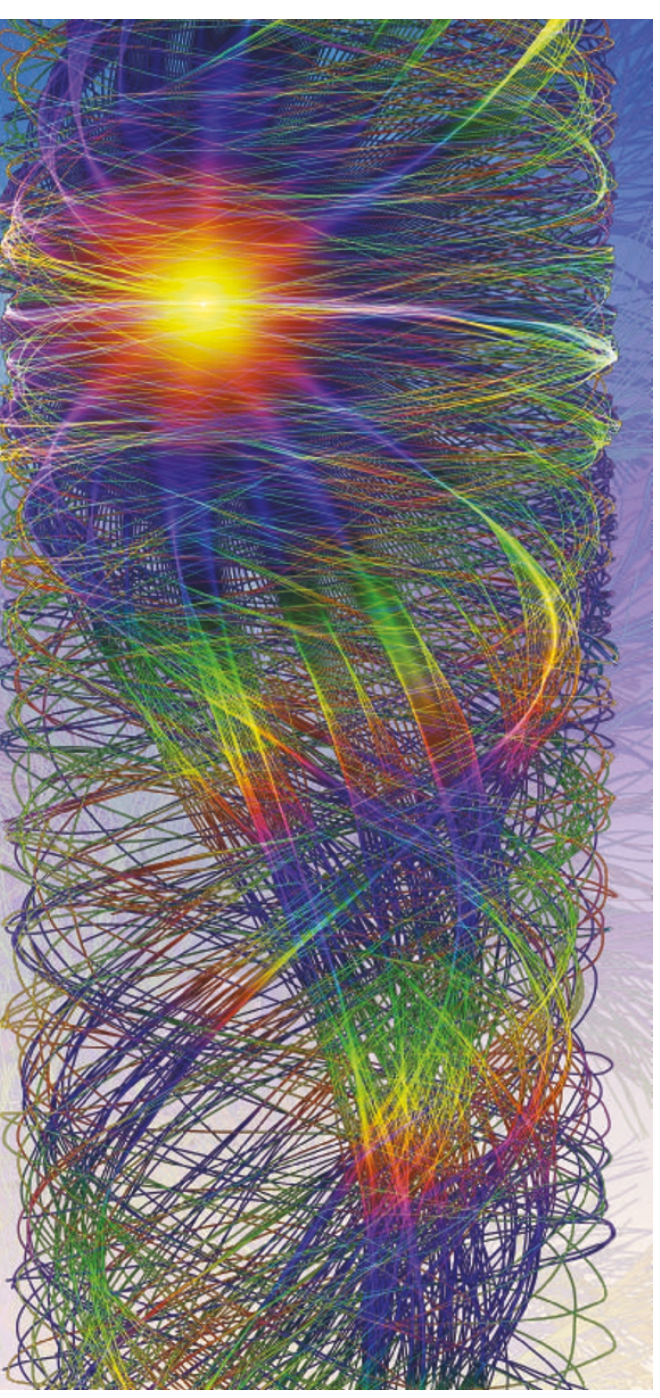

Big business? Interest in nanomaterials, such as this nanowire, has driven a rapid rise in supply and demand.

example - but after discussing their research, Eklund found that the researcher had inadvertently vaporized the tubes while attempting to purify them.

"There is a lack of communication between manufacturers and customers," agrees Mark Banash, the senior engineer at Zyvex, a nanotechnology firm in Richardson, Texas. Banash is the force behind one potential solution to the problem: he runs a certification scheme, under which suppliers are approved if they reach an agreement with Zyvex about the characteristics of the nanotubes they sell and their ability to supply them on time. One supplier has already signed up and Banash says two more should be approved in the next few months. Although the scheme was designed for Zyvex's needs, Banash hopes it will also help other firms to choose suppliers.
Researchers call for more materials science in school

David Cyranoski, Boston

Materials scientists in the United States are mounting a concerted effort to get their discipline taught at high school.

"It's time to stop looking at science as just chemistry, physics or biology. We need to recognize materials science as fundamental," says Michael Rubner, a polymer scientist at the Massachusetts Institute of Technology. “The basic notion of what a materials scientist does should be passed on at the earliest possible time."

Teachers involved in the effort admit that materials science is an unfamiliar concept to their pupils. "I don't think anyone's heard of it," says David Ruth, who teaches at South Seneca High School in Ovid, New York. But Ruth believes that his efforts to bring materials to life are drawing kids in.

Thomas Stoebe, a materials scientist at the University of Washington in Seattle, says the discipline is already reaching schools as a result of week-long teacher-training programmes he has helped to establish. More than 200 teachers across the country have taken the lessons back to their classrooms.

Last month the National Science Foundation brought 90 teachers to a Materials Research Society meeting in Boston for a symposium on teaching materials science in schools. It has also been expanding its Research Experience for Teachers (RET) programme, which sponsors about 140 teachers each summer to train at materials-science departments in leading universities.

RET programmes have helped teachers develop ways of introducing such topics into the classroom. One lesson, developed at Pennsylvania State University, focuses on the question: "How do planes fly?" It includes the construction of a wind tunnel to teach basic concepts in aerodynamics and materials.

But some teachers worry that the No Child Left Behind act, which calls for standardized testing on core subjects, will squeeze out more specialized teaching. "With this programme, we're actually worse off," says Caroline Goode of the National Science Teachers Association in Arlington, Virginia.

Even though programmes that train just a few hundred teachers receive little funding, Rubner says they can still have "an enormous impact" as teachers return from their training programmes and spread the word to others. "It is having a ripple effect," he says. 